\title{
Construction on Multidimensional Homework System for College English on the Background of Internet Plus
}

\author{
Zhengrong Ma \\ Teaching and Research Institute of Foreign Languages, Bohai University, Jinzhou, 121013, China \\ bluestocking@163.com
}

Keywords: internet plus; college English; multidimensional homework system; teaching reform

\begin{abstract}
Homework is an extension of classroom teaching and is a way for teachers to test teaching outcomes and student learning. "Internet plus Education" is a new form of education combined with the continuous development of science and technology and the combination of internet technology and education. In order to meet the demand of college English teaching in the era of "Internet plus", this paper constructs a multidimensional homework system. The current situation of college English homework was investigated. The actual demand for college English teaching reform under the background of "Internet plus" was analyzed. A multidimensional homework system composed of listening work, oral work, reading work, writing work and translation work was constructed. Interesting, hierarchical, richness, openness and motivational innovative application strategies were proposed.
\end{abstract}

\section{Introduction}

The aims of college English teaching are to cultivate students' ability to use English, enhance their awareness of intercultural communication and their interpersonal skills, and at the same time, develop their ability to learn independently and improve their comprehensive literacy so that they can effectively use it in their studies, daily lives, social interactions and future work English, to meet the national, social, school and personal development needs. The application of modern information technology to college English teaching not only realizes the modernization, diversification and convenience of teaching methods, but also changes the teaching philosophy, teaching content and teaching methods. The era of information technology for foreign language teaching provides a new way of learning and unprecedented rich resources ${ }^{[1]}$. Therefore, college English should vigorously promote the integration of the latest information technology and curriculum teaching, and continue to play an important role in modern education technology, especially information technology in foreign language teaching.

In college English teaching, homework can not be neglected because "it is an extension of classroom teaching and a way for teachers to test teaching outcomes and student learning." Students in the process of working independently or in cooperation with others to strengthen and consolidate what they have learned, to broaden their knowledge, improve the ability to analyze and solve problems. "Internet plus Education" is a new form of education combined with the continuous development of science and technology and the combination of internet technology and education. Information technology has infiltrated every aspect of society and has had a profound impact on college English. In order to meet the demand of college English teaching in the era of "Internet plus", this paper constructs a multidimensional homework system for college English. In order to give full play to the role of homework, improve the quality of English teaching and improve students' ability of applying English.

\section{Homework Status of College English}

Many English teachers think that homework is very important to English teaching and an essential part of English teaching process. It is a necessary means for students to create their own 
English learning environment and atmosphere. However, it is unsatisfactory in the actual teaching process. There are still some common problems, which not only reduce students' interest in learning, but also inhibit the development potential of students and fail to give full play to the role of homework. Specifically, there are some problems as follows:

(1) The form of works are monotonous. Under the influence of exam-oriented education, the main objective of college English learning is to pass the English CET-4, AB-level examinations or graduate entrance exams. Teachers pay too much attention to the study of students' ability to memorize, ignoring the comprehension, analysis, synthesis and application of comprehensive ability training. College English assignments are all exam-related or test-related, with written or memorized words, sentence or paragraph translation, reading or writing, and other types of assignments, such as visual, listening, speaking or writing.

(2) There is no difference in contents of works. "Layered Teaching" is the transformation of traditional teaching, not only adapt to individual differences in students, but also to promote students to improve together. At present, college English assignments aim at consolidating and digesting learned knowledge and forming skill skills, disregarding the differences of students, unifying requirements, running through written assignments, and students with better foundation are annoyed and annoyed with a large number of repetitive assignments. Feel not feel the sense of innovation and success brought by homework; students with poor foundation, long-term finished work, teachers do not meet the requirements, resulting in fear of homework psychology.

(3) Lack cooperation to complete the works. Marx said: "Only in the community can the individual acquire the means to fully develop his or her ability." "One's development depends on the development of all other people who are directly or indirectly engaged with him." From this we can see that human development can not be separated from interaction and can not be separated from the collective. English as a communication tool in the learning process, not only need students to complete some tasks autonomously, but also need to work through the group to accomplish certain tasks. Traditional homework assignments are all personal assignments that students complete independently after class or after class.

(4) Work effect is missing. Homework to achieve the effect of promoting teaching, teaching feedback in time the problems that exist, both require students to conscientiously complete, but also require teachers to promptly correct and evaluate. However, the current situation is that students do not have a profound understanding of English homework as a task of completing the arrangement of teachers. The phenomenon of plagiarism is serious and the results of teachers' criticism are not carefully reviewed ${ }^{[2]}$. Teacher research task is heavier, it is difficult to have enough time to modify each student homework, a single content review. Students do not take homework seriously, do not consciously think and do not complete independently, teachers do not complete the job approval and copying of the indulgence, making the college English homework can not retrieve, evaluate and improve English learning.

\section{Teaching Reform for College English on the Background of "Internet Plus"}

"Internet plus" has brought new opportunities for education reform and development. The Internet is breaking down geographical boundaries, living boundaries and learning boundaries so that teachers and students can receive, process and use vast amounts of information to serve themselves anytime, anywhere. The "Internet" has really changed the previous way of learning, changing the way teachers and students grow ${ }^{[3]}$. "Internet plus" permeates college English teaching, promotes the reform of college English teaching, cultivates a large number of excellent English professionals, and accelerates social development and the progress of the times. "Internet plus" has a profound impact on college English teaching.

"Internet plus" has promoted the reform of teaching methods and also realized the teaching content innovation ${ }^{[4]}$. The arrival of "Internet plus" has prompted the optimization and adjustment of the teaching structure of college English courses. Teachers and students can make use of the network to achieve various exchanges and interactions so as to make the learning process more efficient and open. Under the background of "Internet plus", it is possible to change and innovate 
the teaching methods of college English. By virtue of the faster speed of communication, English material can be communicated to students for the first time, effectively improving students' English learning efficiency. "Internet plus" ensures the richness and the contemporary nature of college English teaching content. Students use a variety of Internet channels for knowledge acquisition and information collection, broadens students' horizons and continuously extends the effectiveness of English teaching content.

\section{Construction on Multidimensional Homework System for College English on the Background of "Internet Plus"}

Multidimensional work system refers to the students' feelings, attitudes and values, changes the traditional teaching of a single form, single and single, closes and hinders the development of students mode of operation, conform to the learning rules, multi-angle, multi-directional, multi-form and multi Demand for design homework, expand homework, fully tap all kinds of educational resources, reorganize and adjust resources according to educational goals, communicate the bridge between student life and book world, provide a wide range of emotional background for subject courses, Provide practical platform, pay attention to students' initiative, independent thinking, active exploration and reasonable performance, make the work more humane, let the learning filled with life breath, enable students to release their potential in homework, develop multiple intelligences, experience the pleasure and confidence of learning. Access to the harmonious development of personality. The multi-dimensional operating system of college English under the background of "Internet plus" is composed as follows:

(1) Listening homework. Listening is an important skill of language learning. In TOEFL, IELTS, English major eight, and college English four and six examinations, listening as an important indicator to measure students' English proficiency. The traditional university listening teaching adopts the form of "speaking words, recordings, and answers", seldom focuses on the students 'listening ability cultivation, and students' initiative and autonomy are not fully mobilized. In the "Internet plus" era, with the rapid development of education and science and information technology, a great variety of audio-visual materials in English, various radio programs in the United States and the United States, the communication of information technology, and the internationalization of teaching have been provided to Chinese scholars more learning opportunities and information. The following three forms of listening work most popular ${ }^{[5]}$ : first, English songs, teachers can recommend some characteristic, suitable for practicing English songs; second, the English video to choose from including English learning and English news Video, etc .; third, video clips, arrange some video clips to stimulate student interest.

(2) Spoken homework. Spoken English is a verbal form spoken orally by people in English-speaking countries. English as a language, the most basic function is to communicate and exchange, oral learning is very important. How to learn spoken English effectively has become a hot topic that English educators and English learners pay close attention to. Oral learning is vulnerable to learning situations, learning motivations, phonetic transcription, and vocabulary syntax. In the "Internet plus" era, autonomous learning based on the Internet has become an important learning method for students. The use of APP mobile client to achieve personalized and independent oral English learning has become an effective way to rapidly improve the level of spoken English. Teachers should arrange APP-based oral work to meet students' needs for accurate speech recognition, oral assessment, offline download and online dictionary for spoken English. Not only can students find and collect information for themselves, but also enable students to complete such assignments in groups.

(3) Reading homework. Reading as an important way of language input plays an important role in English teaching. To improve students 'English reading ability is not only the purpose of English study, but also a means of learning English well. It is also a way to test students' English knowledge, cultural knowledge, thinking ability and comprehensive ability to handle information. There are two ways reading assignments can be taken. First, text preview. Teachers design tasks based on questions that are relevant to the content of the lesson so that students can preview it with questions 
and tasks. Teachers can also divide the text into sections, assign it to groups, and assign tasks within the group by students. Second, in online content reading, college English teaching, intensive reading, comprehensive reading and general reading classes all train students' reading ability. However, reading ability is hard to have a qualitative breakthrough if only following teaching materials. Teachers arrange or let students find the web content themselves, and then record the main content, core vocabulary or classic sentences, and share with teachers or classmates to broaden their knowledge and reading volume.

(4) Writing homework. As a form of written expression, English writing has drawn more and more attention. It is a comprehensive reflection of the ability of using English language and is the actual reflection of the degree of English learning. Writing can help students improve the accuracy of using English, expand their English vocabulary, enhance their ability to think logically and analyze problems, and at the same time, they can promote reading, listening, speaking and translating. Typical forms of writing include: First, the English Weekly, requires students to develop good habits, usually observe, use English to record what happens each week, as well as their feelings, feelings and gains, students do not have the psychological burden, you can At your will, boldly write down what you see and hear and what you think and think. Second, the composition of the essay, combined with the flexible arrangement of the lectures and the flexible and versatile style of the essay, allow students to write memos, letters, applications, e-mails, poetry, surveys and research reports in addition to the topic essay.

(5) Translation homework. Translation is the act of transforming one language message into another language message on an accurate and smooth basis. Translation is not a purely technical language appearance variation, but the translator through the original language shape, deeply understand the original author art creation process. College English compulsory phase of class time is limited, and translation as a comprehensive ability to use English, requires a lot of time to practice, so the translation operations are generally arranged for students to complete after class. Specific includes the following three forms: first, the materials in the textbook, select the long sentences from the text or difficult passages for students to translate; second, the extra-curricular materials, select the materials related to each unit topic to enable students to translate , But also can choose to have nothing to do with the textbook; third, post-translation experience, post-translation experience is to rethink the content of translation, thinking about the difficulties encountered in translation, summarizing the method of translation, the improvement of translation ability is very useful.

\section{Innovative Countermeasures on College English Homework on the Background of "Internet Plus"}

Give full play to the "Internet plus" College English multidimensional operating system role in the practical application process, but also need to follow the following strategies:

(1) Interesting. Through the understanding of students' interests and interests, changing the repetitive content and form of boring English assignments in the past, the content designed to stimulate students' curiosity and curiosity is designed to enhance the interest of English homework. Starting from the students 'interests and hobbies, they use the topics often covered by students in their daily life to design, arouse students' enthusiasm for learning and enthusiasm for completing homework and improve the efficiency of English homework ${ }^{[6]}$. Design content rich and new forms of English homework, combined with the development of the times, English teaching to keep pace with the times, and strive to improve students' English communication and communication of the micro-skills.

(2) Hierarchy. Teachers need to pay attention to different levels and different types of homework, to meet the different needs of students. Different levels of students for different levels of exercise, improve the overall learning ability of students. Homework should focus on the consolidation of basic knowledge, focusing on the consolidation of the subject; focus on improving the ability of students, the need to increase the difficulty; taking into account the poor academic performance of students, the design of a less difficult homework. According to the different levels and different 
levels of students to design homework, not only consolidate the students 'basic knowledge, promote the development of students, but also stimulate students' curiosity, help students to build self-confidence, improve the enthusiasm of learning English.

(3) Richness. "Internet plus" offers a wealth of multimedia tools that provide a variety of ways for teachers to assign assignments and students to do their homework. English work in the "Internet plus" era can be students' favorite listening and speaking, or collect information online. Teachers do not need to find all the information during lesson preparation, and students must also be loyal listeners. In the "Internet plus" era, it is particularly important for students to learn to find and collect information. When teachers design their English assignments, they can arrange some homework to find information and cultivate students' ability to collect information.

(4) Openness. Open operation refers to the students' extracurricular assignments that are not sure. The operability of such assignments is very strong. The contents of the assignments and the results of the assignments are not unique. They have the characteristics of autonomous operation and initiative completion. Open space and time work, school, family, community, nature are students work space, homework is not limited to the completion time; job goal is open, not the only goal of knowledge, to encourage students to boldly imagine, and strive to cultivate students' innovative awareness and Innovativeness; job evaluation open, strengthen the "process" awareness, dilute the "result" awareness; operating mode is open, a variety of operating methods comprehensively.

(5) Motivation. Incentive is the key to open the door of the psychological and emotional students, to mobilize the students 'initiative, and promote the enthusiasm of learning and develop students' self-confidence. Timely homework evaluation helps teachers and students emotional communication, so that students develop good learning habits. Therefore, whether job evaluation is motivational is very important. Specific strategies include: pay attention to the job evaluation symbols, make the evaluation more humane; select skillful job evaluation language, let the evaluation of warm students, make good use of multi-directional evaluation, make the evaluation more diverse. Through job evaluation, so that jobs really serve the teaching, and encourage students to study hard.

\section{Acknowledgment}

This work is supported by General B subjects on Teaching reform for Bohai University in 2016 (BDJG2016YB13): On the Background of Internet Plus, Construction on multidimensional homework system for college English A class.

\section{References}

[1] Y. S. Ren, "On the reform and development of education in the era of 'Internet plus'," http://blog.sina.com.cn/s/blog_6f034fc30102vr6w.html, 2018-1-2.

[2] J. F. Liu, F. Zhang, Z. H. Zhao, "A Literature Review of Domestic Research on College English Assignment," Education Teaching Forum, vol. 9, no. 51, pp. 178-179, 2017.

[3] Ministry of Education, "The education revolution of the "Internet plus" era," http://old.moe. gov.cn// publicfiles/business/htmlfiles/moe/s7822/201504/186055.html, 2018-1-2.

[4] S. C. Ying, Y. M. Fu, "Study on the Practice of English Teaching Reform in Colleges and Universities under the Background of Internet plus," Journal of HUBEI Correspondence University, vol. 30, no. 14, pp. 161-162, 2017.

[5] Y. H. Niu, Y. Yu, "A new probe into the diversification of College English homework design," Science \& Technology Information, vol. 28, no. 20, pp. 438-439, 2011.

[6] The five-star library, "Study on the effectiveness of high school English homework," http://wxphp.com/wxd_2ad0f8s52e9kcel7h0sk_1.html, 2018-1-2. 